\title{
TERRITORIALITY AND FLOCK FORMATION AS POSSIBLE MECHANISMS FOR MAINTAINING SPECIES STABILITY: COMMENTARY ON V. G. GORSHKOV, A. M. MAKARIEVA (2020) "KEY ECOLOGICAL PARAMETERS OF IMMOBILE AND LOCOMOTIVE LIFE"
}

\author{
V. M. Gavrilov \\ Lomonosov Moscow State University, 1 Leninskiye Gory, Moscow, 119991, Russia \\ E-mail:vmgavrilov@mail.ru
}

\begin{abstract}
In the work of Gorshkov and Makarieva [1] an idea was put forward that the formation of a continuous cover by immobile organisms (the so-called "lack of space abundance") allows the species to effectively expel non-competitive individuals from the population thus maintaining genetic stability. An analogue of such "lack of space abundance" (continuous cover) is the territoriality in birds, when all areas suitable for reproduction are occupied and defended against intrusions of competitors. In the regime of territoriality, competition during the period of reproduction occurs only between close neighbors that are normally not numerous. This appears to be insufficient for the maintenance of species stability in birds, as during migration and overwintering birds assemble into big flocks where population densities and the intensity of competitive interaction become higher. Immobile organisms, on the other hand, are able to compete with their immediate neighbors only. This leads to the conclusion that, for such local competitive interaction to be effective, the frequency of appearance of non-competitive individuals in immobile organisms should be significantly lower than in locomotive organisms (birds).
\end{abstract}

Keywords: ecological stability, competition, population structure, avian energetics, basal metabolism.

For citation: Gavrilov V. M. Territoriality and flock formation as possible mechanisms for maintaining species stability: commentary on V. G. Gorshkov, A. M. Makarieva (2020) "Key ecological parameters of immobile and locomotive life". Russian Journal of Ecosystem Ecology. 2020;5(3). Available from: https://doi.org/10.21685/25000578-2020-3-5

\section{ТЕРРИТОРИАЛЬНОСТЬ И ОБРАЗОВАНИЕ СТАЙ КАК ВОЗМОЖНЫЕ МЕХАНИЗМЫ ПОААЕРЖАНИЯ ВИАОВОЙ УСТОЙЧИВОСТИ У ПТИЦ (КОММЕНТАРИЙ К СТАТЬЕ В. Г. ГОРШКОВА, А. М. МАКАРЬЕВОЙ “ФУНААМЕНТАЛЬНЫЕ ЭКОЛОГИЧЕСКИЕ ПАРАМЕТРЫ НЕПОАВИЖНОЙ И ПЕРЕАВИГАЮЩЕЙСЯ ЖИЗНИ”)}

\section{В. М. Гаврилов}

Московский государственный университет им. М. В. Ломоносова, Россия, 119991, г. Москва, Ленинские Горы, 1 E-mail:vmgavrilov@mail.ru

Аннотация. В работе Горшкова и Макарьевой [1] высказана идея о том, что образование сплошного покрова неподвижными организмами (так называемое «отсутствие изобилия пространства») позволяет виду эффективно выбраковывать неконкурентоспособных особей, поддерживая генетическую устойчивость. Аналогом «отсутствия изобилия пространства» у птиц является территориальность, когда все пригодные для размножения особей территории заняты и охраняются от вторжения конкурентов. При этом конкуренция во время периода размножения происходит только с ближайшими немногочисленными соседями. По-видимому, этого недостаточно для поддержания видовой устойчивости у птиц, поэтому во время миграций и зимовки птицы объединяются в большие стаи, в которых плотности численности особей и интенсивность конкурентного взаимодействия возрастает. Неподвижные же организмы могут конкурировать только с ближайшими соседями. Это позволяет предположить, что частота появления неконкурентоспособных особей у неподвижных 
организмов должна быть существенно ниже, чем у передвигающихся (птиц), чтобы локальный отбор был эффективным.

Ключевые слова: экологическая устойчивость, конкуренция, структура популяции, энергетика птиц, базальный метаболизм.

\section{Introduction}

I knew V. G. Gorshkov for many years (beginning from the 1970s) and many of his ideas appeal to me as very valuable, among them the definition of immobile and locomotive life. This definition derives from the existence of two magnitudes characterizing energy fluxes in life. One is the flux of primary productivity of the biosphere (the photosynthetic power) per unit surface area, which is of the order of $1 \mathrm{~W} / \mathrm{m}^{2}$. Another is the characteristic flux of energy consumption per unit mass or unit volume of a living body. It is called specific metabolic rate and is of the order of $1 \mathrm{~W} / \mathrm{kg}$ or $10^{3} \mathrm{~W} / \mathrm{m}^{3}$. The ratio of these two fluxes produces a critical linear body size of the order of $l_{\max } \sim 10^{-3} \mathrm{~m}$, i.e. one millimeter. This critical size separates the immobile life from the locomotive life. Organisms smaller than the critical size do not need to move; they can stay where they are living on the fluxes of photosynthesis. Larger organisms have to move and consume the stores of biomass [2].

Remarkably, the notion of a universal, sizeindependent metabolic rate characterizing life as a whole, was formulated by V. G. Gorshkov as early as in 1981 on the basis of a quite limited amount of empirical data [3]. Later it found a brilliant confirmation with much more extensive analyses including thousands of species by both V. G. Gorshkov and his colleagues [4] as well as by independent researchers $[5,6]$. For example, published data on metabolic rates in prokaryotes were collected and it was shown that, on average, the mass-specific endogenous metabolic rates in prokaryotes coincides with specific basal metabolic rates in the largest animals [4].

A most important property of life repeatedly emphasized by V. G. Gorshkov is the ability to form a continuous cover on the Earth's surface. Work [1] presents a new fundamental idea that the immobile organisms that form a continuous cover and experience lack of space abundance perform competitive interaction most efficiently. It is proposed that any defective mutant finds itself surrounded by normal individuals and is forced out of the population. Locomotive organisms cannot in principle form a continuous cover and exist under conditions of abundant free space. Defective individuals of the locomotive species can use this vacant space to escape competitive interaction with normal individuals and reproduce to reach high numbers - a scenario that may inflict disintegration of the ecological community and its environment. This new idea unites the principles of genetic and ecological stability. Both relate to the immobility and the small body size.

\section{Territoriality in birds}

In zoology, we deal with the locomotive life only. Considering how locomotive life differs from immobile life facilitates a better understanding of both. Species stability in animals is ensured not just by morphological and physiological adaptations at the organismal level, but also by specific population-level mechanisms. Such mechanisms should ensure both the species stability as well as the stability of the ecological community to which it belongs, in particular, by excluding the possibility of the species' food base exhausting. Due to their high mobility and belonging to a high trophic level in the community, the birds should have mechanisms confining their population numbers.

The maintenance of population numbers at a level significantly below the food base capacity occurs via regulation of population density. The most rational way of regulating population density is territoriality. All the area where the population is able to live is divided into individual territories. In the regime of monogamy, each such territory belongs to a pair of reproducing individuals who defend it against any possible competitors. In the regime of polygyny, the role of "a pair" is played by the male with his females (polygyny) or the female with her males (polyandry). In this case, the territory is defended not against the strangers but also against the mating partners. In some sense, territoriality is analogous to the lack of space abundance for the immobile organisms - all available habitats are occupied and defended against intruders.

Birds defend their territory by interacting with immediate neighbors at its borders using sound signals and demonstrative behavior. As a rule, these manifestations go without conflicts and, apparently, such behavior cannot be too energy consuming. Singing of passerine birds is a quite efficient way of stably marking their individual territories at minimal energetic costs.

It is important to research, first, how territories are appropriated by individuals in different species and, second, how the territorial division may affect the structure of the population. Size of individual 
territory can signal about the social rank of the individual as well as indicate its competitive capacity. The criteria that determine individual competitiveness depend on the conditions of specific habitats but should also reflect the social structure of the population. The highest social rank characterizes individuals that are most competitive in the local habitat.

Our research of fundamental energetics in birds [7-15] and population investigations of model spe-
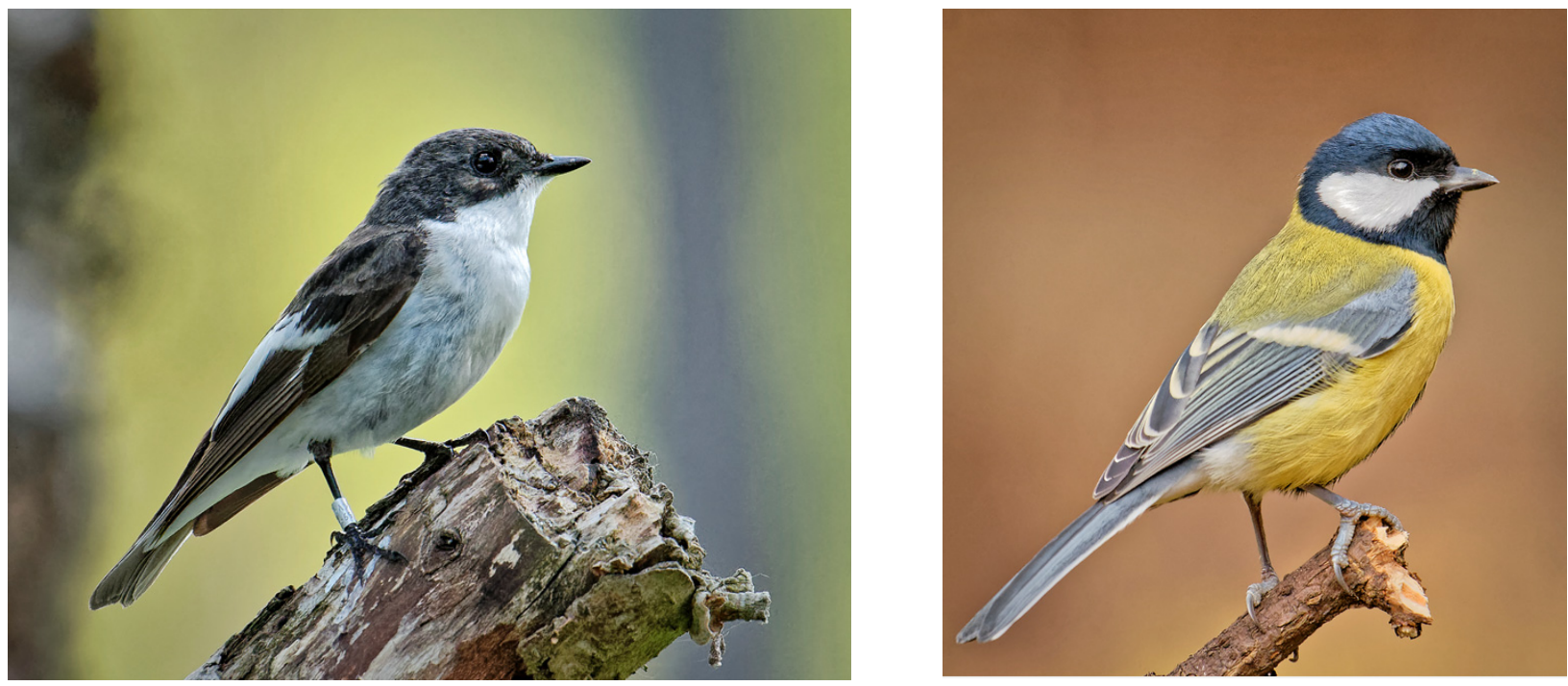

Fig. 1. Model bird species used in population studies (see text for details), the European pied flycatcher Ficedula hypoleuca (left) and the great tit Parus major (right)

Individuals with a higher basal metabolic rate can endure wider fluctuations of ambient temperature, perform greater work and display higher productivity. A high basal metabolic rate commits the organism to become more euryphagous (i.e. be able to consume more diverse food resources) and acquire a greater ecological plasticity. On the other hand, it requires that the organism should occupy habitats with a high energy flow, i.e. optimal habitats. Hence, males with a higher basal metabolic rate should tend to occupy individual territories in more optimal habitats.

The advantages of a higher basal metabolic rate include a higher probability of successful nesting at low temperatures (e.g., in early spring or at high latitudes) and a possibility of using energydemanding behavioral strategies. Differences in basal metabolic rate lay the ground for the population structure: males with a high basal metabolic rate claim larger and better nesting territories and behave more energetically (e.g. singing more actively or defending a larger territory).

Population studies of the great tit have shown that the high rank of males (a high basal metabolic rate and some morphological parameters) determine their choice of nesting territories in optimal habitats [16, 18-20]. This entails advantages for a cies (Fig. 1) [16-20] allowed us to propose that basal metabolic rate can be used as a proxy of functional capacities of birds with different social ranks and phenotypes. It can also be used as a quantitative framework for describing the diversity of individuals in a population. Basal metabolic rate is one of the most informative energetic parameters; it can make for a high objective standard of comparisons between individuals [11-13]. 
inclined to live a nomadic life (marginal existence), since imprinting of a "deficient" territory appears to be less persistent or does not occur at all.

One should bear in mind that while all individuals grown up in the optimal habitat have higher than average morphological and physiological characteristics, only a few of them will inherit the individual territory from their parents. The rest have two opportunities: they can either force out the offspring of less elite parents from their suboptimal individual territories, or disperse. Forcing out other individuals from the suboptimal territories is not always possible. The progeny of lower-ranking parents can compensate their morphological and physiological disadvantages by their better knowledge of their home territory. Another reason is that it is the optimal territory that is imprinted.

At least two casts form in the population: territorial and nomadic. The dispersing individuals, if they find favorable habitats, can become territorial and acquire a high rank in the new habitat. In other cases, individuals with superior morphological and physiological parameters become nomadic representing a certain reserve for occupying new territories. This explains the presence in winter flocks of individuals with a high basal metabolic rate. Con- tinuously dispersing individuals originating from the optimal parts of the habitat (where competitive relationships are most pronounced) can gradually spread into all suitable habitats until all vacant niches are occupied. The ideas of V. G. Gorshkov, in particular, the fundamental properties of life he outlined, including expansion as a mechanism of maintaining stability (see Section 4.1 in [28]), clarify the mechanisms by which the species fully occupies the entire area suitable for its existence.

The general pattern we have discussed should apply to a particular flock (population) and to a species as a whole. On a larger scale of the entire area occupied by the species, this scheme should be pronounced most clearly due to a large gradient of external conditions. On a smaller scale, the observed patterns should be more dependent on local conditions. In many cases, the peripheral territories are not truly "deficient", so this scheme might not be fully identifiable. However, the tendency for the progeny of high-ranking individuals to occupy optimal habitats is sufficiently clear. Territoriality is the main factor of population structuring. Namely a better and a larger territory is the leading stimulus for competitive interactions within a population (Fig. 2).

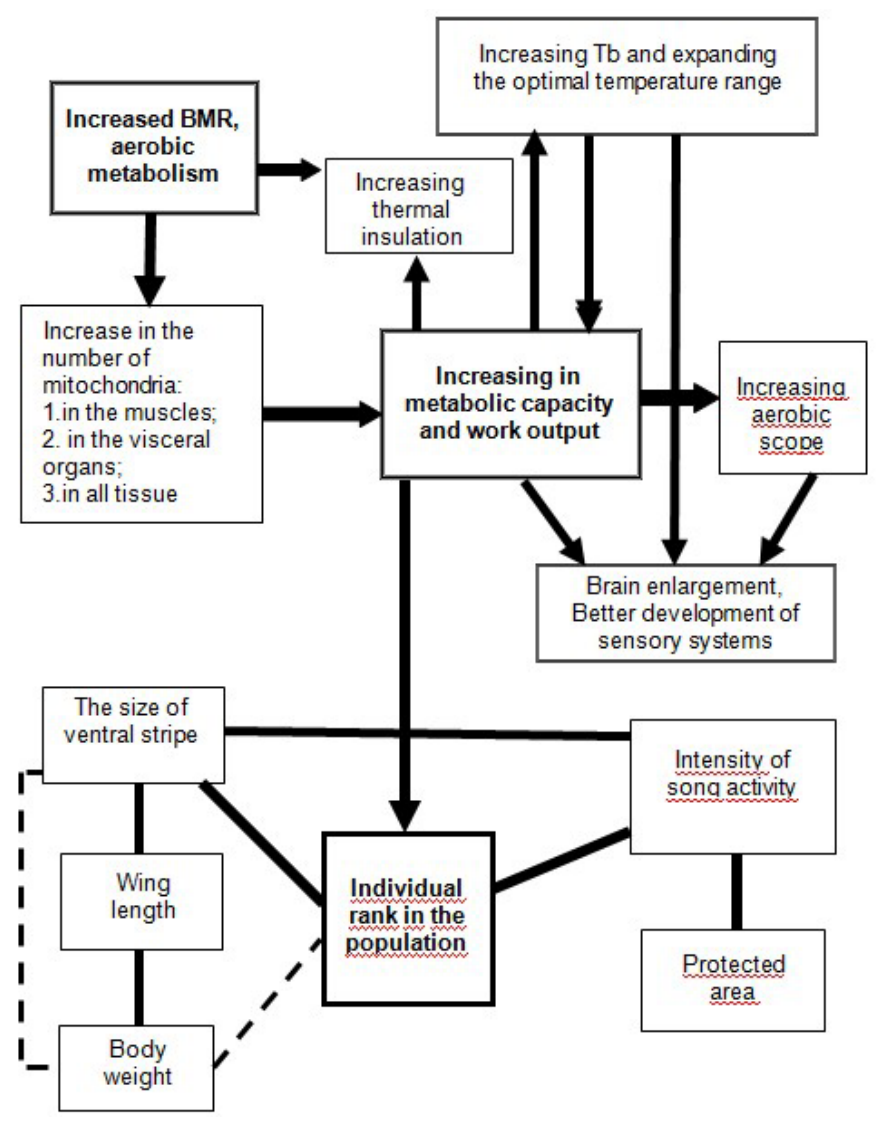

Fig. 2. A principal scheme of how an increase in basal metabolic rate (BMR) can affect the morphological and physiological properties (and ultimately the social rank) of individuals and how the rank is correlated with morphological and population properties. Arrows show links that are common to all animals; bold lines in the lower part of the diagram show statistically significant correlations established for the great tit; dashed lines indicate statistically insignificant relationships. Tb is body temperature 


\section{Flock formation and competitive interaction}

Territoriality during the period of reproduction hinders competitive interaction (comparison) between individuals - with an exception of territorial lekking birds like grouses, some sandpipers and others. In all other cases territoriality, in the presence of sexual dimorphism, is inevitably associated with monogamy. Even males of the highest rank can only couple with his closest neighboring females. They cannot reach to distant territories due to energetic constraints.

Although monogamy makes the elimination of the less competitive individuals less efficient, it has the advantage of improving progeny upbringing and extending the species' ecological niche especially when there is sexual dimorphism in body size. Monogamy allows the offspring to be born physiologically immature, which has an evolutionary advantage. The genetic code does not have to include a rigid behavioral program; the behavior is formed and tuned with a higher precision via teaching and imprinting. The imprinting does not need to be rigid either.

To control population densities, it suffices to maintain territoriality during the reproduction period. As the reproduction period is over, birds may lose the instinct of territoriality and flocks, as many species do. Many passerine birds cease singing, abandon their individual territories and assemble in flocks.

As competitive interaction is less intense during the period of territoriality, there should necessarily exist a period for enhanced competition without territoriality. This more intense competitive interaction involves elimination of the less competitive individuals during the most critical time of the annual cycle. In many birds this critical time is overwintering, during which they form flocks often with a rigid hierarchy. Namely during this period all individuals in the population are ranked. High rank of a male in the flock determines his priority for choosing a territory in an optimal habitat. This increases the chances for survival of both the dominant individuals and their progeny. Two types of competitive interaction are combined. First, the less competitive individuals are eliminated from the population in the interim between the reproductive periods. Second, the birth rates of the remaining less competitive individuals are reduced when, during the reproduction, they are forced out to the least productive territories or suboptimal habitats.

\section{Conclusions}

Individuals in a population while featuring the same species-specific genetic information can dif- fer by a considerable number of traits that determine their ranking within the population. Interaction between individuals in a population tends to identify individuals that react most adequately to changing environmental conditions. In the result of this comparison, or competition, the population gets structured reflecting the effects of both external and internal factors, the latter related to the phenotypic diversity of individuals. From this point of view, the interaction between individuals in the population is stabilizing. It tends to maintain maximum stability (competitiveness) of the population system as a whole.

The concept of the biotic regulation of the environment formulated by V. G. Gorshkov [28] emphasizes the necessity of a simultaneous maintenance of the genetic stability of species and environmental stability. On the example of the birds, one can see that these two mechanisms of stabilization can be realized separately in space and time. The regulation of population numbers that prevents the depletion of the food base occurs via territoriality during the period of reproduction. The regulation of competitiveness (genetic adequacy of the individuals) is more rigorously performed via formation of large flocks during migration and overwintering.

In the smallest organisms with their linear body size $l<l_{\max }$ satisfying the notion of immobile life as discussed by Gorshkov and Makarieva [1] both mechanisms must function simultaneously. Competition with the close neighbors should suffice for an unambiguous identification of noncompetitive individuals and forcing them out from the population. It appears that, in order this condition to fulfill, the proportion of noncompetitive individuals in the population should be small - such that when a noncompetitive individual is born, it can be forced out from the population by immediate competitive neighbors. In this context it should be noted that large organisms differ from small ones not only by their size, but also by the rate of accumulation of genetic mutations [29-31]. The probability of appearance of mutations in large organisms with large genomes is several orders of magnitude higher than in small organisms with small genomes. I believe that a further analysis of the fundamental problem about how the mechanisms of genetic and ecological stability relate to each other in differentsized species requires serious interdisciplinary research. V. G. Gorshkov's concept of the biotic regulation provides a fundamental theoretical basis for conducting such research.

\section{Библиографический список}

1. Gorshkov, V. G. Key ecological parameters of immotile versus locomotive life / V. G. Gorshkov, A. M. Makarieva // Russian Journal of Ecosystem Ecology. - 2020. - Vol. 5 (1). - P. 1-18. - DOI 10.21685/2500-05782020-1-1. 
2. Gorshkov, V. G. The Structure of the Biospheric Energy Flows / V. G. Gorshkov // Botanical Journal. - 1980. Vol. 65 (11). - P. 1579-1590.

3. Gorshkov, V. G. The Distribution of Energy Flows among the Organisms of Different Dimensions / V. G. Gorshkov // Journal of General Biology. - 1981. - Vol. 42 (3). - P. 417-429.

4. Mean mass-specific metabolic rates are strikingly similar across life's major domains: Evidence for life's metabolic optimum / A. M. Makarieva, V. G. Gorshkov, B.-L. Li, S. L. Chown, P. B. Reich, V. M. Gavrilov // Proceedings of the National Academy of Sciences U.S.A. - 2008. - Vol. 105 (44). - P. 16994-16999. - DOI 10.1073/ pnas.0802148105.

5. Kiørboe, T. Shifts in mass scaling of respiration, feeding, and growth rates across life-form transitions in marine pelagic organisms / T. Kiørboe, A. G. Hirst // American Naturalist. - 2014. - Vol. 83 (4). - P. E118-E130. DOI $10.1086 / 675241$.

6. Linking scaling laws across eukaryotes / I. A. Hatton, A. P. Dobson, D. Storch, E. D. Galbraith, M. Loreau // Proceedings of the National Academy of Sciences. - 2019. - Vol. 116 (43). - P. 21616-21622. DOI 10.1073/pnas.1900492116.

7. Gavrilov, V. M. Effect of temperature on energy metabolism of a homoiothermal organism as studied in the Great Tit (Parus major, Passeriformes, Aves) / V. M. Gavrilov // Doklady Biological Sciences. - 1994. - Vol. 334. P. 51-56.

8. Gavrilov, V. M. Maximal, potential productive and normal levels of existence metabolism in passerines and nonpasserine birds: I. Dependence on ambient temperatures, seasonal changes, relations to other levels of metabolism and body size / V. M. Gavrilov // Zool. Zh. - 1995. - Vol. 74 (3). - P. 102-122.

9. Gavrilov, V. M. Maximal, potential productive and normal levels of existence metabolism in passerines and nonpasserine birds: II. Relations to the level of external work, energetics and ecological effects / V. M. Gavrilov // Zool. Zh. - 1995. - Vol. 74 (4). - P. 108-123.

10. Gavrilov, V. M. Maximal level of daily external work in homoiothermal animals: relations to basal metabolic rate and body size / V. M. Gavrilov // Doklady Biological Sciences. - 1995. - Vol. 342. - P. 708-712.

11. Gavrilov, V. M. Basal metabolic rate in homoiothermal animals: 1. Scale of power and fundamental characteristics of energetics / V. M. Gavrilov // Zh. Obshch. Biol. - 1996. - Vol. 57 (3). - P. 326-345.

12. Gavrilov, V. M. Basal metabolic rate in homoiothermal animals: 2. Origin in the course of evolution, energetic and ecological effects / V. M. Gavrilov // Zh. Obsch. Biol. - 1996. - Vol. 57 (4). - P. 421-439.

13. Gavrilov, V. M. Energetics and Avian behavior / V. M. Gavrilov. - Amsterdam : Harwood Academic Publishers, 1997. $-225 \mathrm{p}$.

14. Gavrilov, V. M. Comparative energetics of passerine and non-passerine birds: differences in maximal, potential productive and normal levels of existence metabolism and their ecological implication / V. M. Gavrilov ; ed. by N. Adams, R. Slotow // Proc. 22 Int. Ornithol. Congr., Durban. - Johannesburg : BirdLife South Africa, 1999. - P. 338-369.

15. Gavrilov, V. M. Ecological and scaling analysis of the energy expenditure of rest, activity, flight, and evaporative water loss in Passeriformes and non-Passeriformes in relation to seasonal migrations and to the occupation of boreal stations in high and moderate latitudes / V. M. Gavrilov // Q. Rev. Biol. - 2014. - Vol. 89. - P. 107-150. DOI 10.1086/676046.

16. Kerimov, A. B. Dynamics of Morphophysiological Correlatives of Social Status during the Annual Cycle of the Great Tit (Parus major, Passeriformes, Aves) / A. B. Kerimov, E. V. Ivankina, T. A. Il'ina, V. M. Gavrilov // Doklady Biological Sciences. - 1994. - Vol. 334. - P. 57-60.

17. Gavrilov, V. M. Population-geographical variations in the color of plumage and metabolism of males of different color morphs in the pied flycatcher Ficedula hypoleuca / V. M. Gavrilov, A. B. Kerimov, E. V. Ivankina // Doklady Biological Sciences. - 1993. - Vol. 333. - P. 608-610.

18. Population and ecological effects of variation and interaction of energetic parameters in birds with special reference to Great Tit (Parus major) and Pied Flycatcher (Ficedula hypoleuca) / V. M. Gavrilov, A. B. Kerimov, T. B. Golubeva, E. V. Ivankina, T. A. Ilyina // Avian ecology and behavior. - 1998. - Vol. 1. - P. 87-101.

19. Energy aspects of the formation of territoriality as a complex form behaviors and basics of bird population structuring / V. M. Gavrilov, A. B. Kerimov, T. B. Golubeva, E. V. Ivankina, T. A. Il'ina // Successes of the modern biology. - 1999. - Vol. 119 (3). - P. 271-284.

20. Nagy, K. A. Relationships between field metabolic rate, basal metabolic rate and territoriality in passerines / K. A. Nagy, V. M. Gavrilov, A. B. Kerimov, E. V. Ivankina ; ed. by N. Adams, R. Slotow // Proc. 22 Int. Ornithol. Congr., Durban. - Johannesburg : BirdLife South Africa, 1999. - P. 390-400.

21. Hixon, M. A. Territory area, flower density, and time budgeting in hummingbirds: An experimental and theoretical analysis / M. A. Hixon, F. L. Carpenter, D. C. Paton // Amer. Natur. - 1983. - Vol. 122 (3). - P. 366-391. DOI $10.1086 / 284141$.

22. Hixon, M. A. Distinguishing energy maximizers from time minimizers: A comparative study of two hummingbird species / M. A. Hixon, F. L. Carpenter // Amer. Zool. - 1988. - Vol. 28 (3). - P. 913-925. - DOI 10.1093/ $\mathrm{icb} / 28.3 .913$.

23. Finch, D. M. Parental expenditure of time and energy in the Abert's towhee (Pipilo aberti) / D. M. Finch // The Auk. - 1984. - Vol. 101 (3). - P. 473-485. - DOI 10.1093/auk/101.3.473. 
24. Davies, N. B. The influence of food on time budgets and timing of breeding of the Dunnock Prunella modularis / N. B. Davies, A. Lundberg // Ibis. - 1985. - Vol. 127 (1). - P. 100-110. - DOI 10.1111/j.1474919X.1985.tb05040.x.

25. Carpenter, F. L. Introduction to the symposium: Territoriality: conceptual advances in field and theoretical studies / F. L. Carpenter // Amer. Zool. - 1987. - Vol. 27 (2). - P. 223-228. - DOI 10.1093/icb/27.2.223.

26. Prescot, D. R. C. Feeding-time minimization and the territorial behavior of the Willow Flycatcher (Empidonax traillii) / D. R. C. Prescot, A. L. A. Middleton // The Auk. - 1988. - Vol. 105 (1). - P. 17-28. - DOI 10.1093/auk/105.1.17.

27. Weathers, W. W. Juvenile foraging proficiency, parental effort, and avian reproductive success / W. W. Weathers, K. A. Sullivan // Ecol. Monogr. - 1989. - Vol. 59. - P. 223-246. - DOI 10.2307/1942600.

28. Gorshkov, V. G. Physical and biological bases of life stability. Man, biota, environment / V. G. Gorshkov. - Berlin : Springer, 1995. - 340 p. - DOI 10.1007/978-3-642-85001-1.

29. Gorshkov, V. G. Dependence of heterozygosity on body weight in mammals / V. G. Gorshkov, A. M. Makar'eva // Doklady Biological Sciences. - 1997. - Vol. 355. - P. 384-386.

30. Gorshkov, V. G. The program of life stability / V. G. Gorshkov, A. M. Makarieva // Biology in School. - 2016. № 8 (2016). - P. 10-20.

31. Makarieva, A. M. Stability of the information of life. Part I. Preventing the decay of the genetic information of life / A. M. Makarieva, V. G. Gorshkov // Energy: Economics, Technology, Ecology. - 2016. - № 3 (2016). - P. 47-54.

\section{References}

1. Gorshkov V. G., Makarieva A. M. Russian Journal of Ecosystem Ecology. 2020, vol. 5 (1), pp. 1-18. DOI 10.21685/2500-0578-2020-1-1.

2. Gorshkov V. G. Botanical Journal. 1980, vol. 65 (11), pp. 1579-1590.

3. Gorshkov V. G. Journal of General Biology. 1981, vol. 42 (3), pp. 417-429.

4. Makarieva A. M., Gorshkov, Li B.-L., Chown S. L., Reich P. B., Gavrilov V. M. Proceedings of the National Academy of Sciences U.S.A. 2008, vol. 105 (44), pp. 16994-16999. DOI 10.1073/pnas.0802148105.

5. Kiørboe T., Hirst A. G. American Naturalist. 2014, vol. 83 (4), pp. E118-E130. DOI 10.1086/675241.

6. Hatton I. A., Dobson A. P., Storch D., Galbraith E. D., Loreau M. Proceedings of the National Academy of Sciences. 2019, vol. 116 (43), pp. 21616-21622. DOI 10.1073/pnas.1900492116.

7. Gavrilov V. M. Doklady Biological Sciences. 1994, vol. 334, pp. 51-56.

8. Gavrilov V. M. Zool. Zh. 1995, vol. 74 (3), pp. 102-122.

9. Gavrilov V. M. Zool. Zh. 1995, vol. 74 (4), pp. 108-123.

10. Gavrilov V. M. Doklady Biological Sciences [Reports of Biological Sciences]. 1995, vol. 342, pp. 708-712.

11. Gavrilov V. M. Zh. Obshch. Biol. [Journal of General Biology] 1996, vol. 57 (3), pp. 326-345.

12. Gavrilov V. M. Zh. Obsch. Biol. [Journal of General Biology] 1996, vol. 57 (4), pp. 421-439.

13. Gavrilov V. M. Energetics and Avian behavior. Amsterdam: Harwood Academic Publishers, 1997, 225 p.

14. Gavrilov V. M. Proc. 22 Int. Ornithol. Congr., Durban. Johannesburg: BirdLife South Africa, 1999 , pp. 338-369.

15. Gavrilov V. M. Q. Rev. Biol. 2014, vol. 89, pp. 107-150. DOI 10.1086/676046.

16. Kerimov A. B., Ivankina E. V., Il'ina T. A., Gavrilov V. M. Doklady Biological Sciences. [Reports of Biological Sciences]. 1994, vol. 334, pp. 57-60.

17. Gavrilov V. M., Kerimov A. B., Ivankina E. V. Doklady Biological Sciences. [Reports of Biological Sciences]. 1993, vol. 333, pp. 608-610.

18. Gavrilov V. M., Kerimov A. B., Golubeva T. B., Ivankina E. V., Ilyina T. A. Avian ecology and behavior. 1998, vol. 1, pp. 87-101.

19. Gavrilov V. M., Kerimov A. B., Golubeva T. B., Ivankina E. V., Il'ina T. A. Successes of the modern biology. 1999, vol. 119 (3), pp. 271-284.

20. Nagy K. A., Gavrilov V. M., Kerimov A. B., Ivankina E. V. Proc. 22 Int. Ornithol. Congr., Durban. Johannesburg: BirdLife South Africa, 1999, pp. 390-400.

21. Hixon M. A., Carpenter F. L., Paton D. C. Amer. Natur. 1983, vol. 122 (3), pp. 366-391. DOI 10.1086/284141.

22. Hixon M. A., Carpenter F. L. Amer. Zool. 1988, vol. 28 (3), pp. 913-925. DOI 10.1093/icb/28.3.913.

23. Finch D. M. The Auk. 1984, vol. 101 (3), pp. 473-485. DOI 10.1093/auk/101.3.473.

24. Davies N. B., Lundberg A. Ibis. 1985, vol. 127 (1), pp. 100-110. DOI 10.1111/j.1474-919X.1985.tb05040.x.

25. Carpenter F. L. Amer. Zool. 1987, vol. 27 (2), pp. 223-228. DOI 10.1093/icb/27.2.223.

26. Prescot D. R. C., Middleton A. L. A. The Auk. 1988, vol. 105 (1), pp. 17-28. DOI 10.1093/auk/105.1.17.

27. Weathers W. W., Sullivan K. A. Ecol. Monogr. 1989, vol. 59, pp. 223-246. DOI 10.2307/1942600.

28. Gorshkov V. G. Physical and biological bases of life stability. Man, biota, environment. Berlin: Springer, 1995, 340 p. DOI 10.1007/978-3-642-85001-1.

29. Gorshkov V. G., Makar'eva A. M. Doklady Biological Sciences. [Reports of Biological Sciences]. 1997, vol. 355, pp. 384-386.

30. Gorshkov V. G., Makarieva A. M. Biology in School. 2016, no. 8 (2016), pp. 10-20.

31. Makarieva A. M., Gorshkov V. G. Energy: Economics, Technology, Ecology. 2016, no. 3 (2016), pp. 47-54. 